Vol. XXV No 2

\title{
A STUDY OF THE FAMILY STRUCTURE IN RELATION TO EMOTIONAL INTELLIGENCE OF HIGH SCHOOL STUDENTS
}

\author{
Valentin LUPU \\ “Nicolae Bălcescu” Land Forces Academy, Sibiu, Romania \\ valilupu@aol.com
}

\begin{abstract}
The current study assessed and compared the emotional intelligence of 75 high school students who grew up with different family structures. High school students between the ages of 16-18 years were randomly selected from high schools in Bucharest, Romania. The General Emotional Intelligence Scale (GEIS) was used to measure the level of their emotional intelligence. In addition, a nonverbal test consisting of 20 face photoswith different facial expressions was used to measure a specific aspect of emotional intelligence, perceiving emotions. Results revealed that family structure does not influence emotional intelligence; however, when looking at the aspect of perceiving emotions, family structure influences this aspect of emotional intelligence.
\end{abstract}

\section{Keywords: emotional intelligence, family structure, perceiving emotions}

\section{Introduction}

In the context of Romania joining the EU and of globalization, the Romanian society has encountered economic and social changes. One important change in the Romanian society is work migration, which has an impact on the structure of the family. The rise in opportunities for employment abroad combined with a desire for higher income has resulted in a decrease of the time parents spend with their children. In fact, it is known that the time a child spends at school is higher than the time he spends at home with a parent. In 2007, a research study done by UNICEF in collaboration with governmental institutions in Romania on the subject of work migration and the influence of this phenomena on children who are left behind at home concluded: "170,000 students, V - VIII grades, have at least one parent working in a different country. From all of these students, 55,000 students have their mother gone, 80,000 students have their father gone and 35,000 students have both parents gone to work in a different country" [1]. There are various non-governmental organizations such as Save the Children who affirm that the number of children who are affected by work migration is around 250,000 [2].

Another alarming phenomenon in Romania is the rising divorce rate. The National Institute of Statistics mentions that the divorce rate for 1000 people in 2010 was 1.76 compared with 1.6 in 2004 . The same institution reveals that of the total number of babies born in 2009, 27.97\% had mothers who were not married [3]. Eurostat, the EU Institute of Statistics revealed that the number of marriage licenses in Romania dropped from $8.27 / 1000$ people in 2007 to $5.2 / 1000$ people in 2011 [4].

Daniel Goleman, in his book, Emotional Intelligence, states that you learn emotional intelligence in your family [5]. LeDoux 
also believes that children's interaction with theircaretakersin their first years of life helps to form a set of emotional lessons, lessons which later in life will be used daily [6]. A meta-analysis of 668 studiespointed out that the development of emotional intelligence has an effect not only on the improvement of behaviour, but it also has an effect on academic performance [7]. Emotional intelligence is an important variable for personal realizations, carrier success, leadership and life satisfaction [8].

\section{Research Objective}

The present study measures the emotional intelligence of high school students and investigates if the family structure in which a student is raised and his gender have an influence on his emotional intelligence.

\section{Research Hypothesis}

a. We anticipate discovering that there is a correlation between emotional intelligence and family structure and gender.

b. We anticipate discovering that students with a higher level of emotional intelligence can more easily recognize the emotions of others around them.

\section{Research Design}

The current study is a correlational study which usedone-way ANOVA and t-test. The dependent variables (VD) are emotional intelligence and perceiving emotions and the independent variables are family structure (nuclear family, singleparent family and grandparents or others) and gender (male, female).

\section{Sample}

The study sample consisted of 75 high school students in the age range of $16-18$ years. 42 students were male and 33 students were female. We had 25 students who were raised in a single-parent family, 25 students raised in a nuclear family and 25 students raised by grandparents or other persons such as relatives or neighbours. Participation was voluntary.

\section{Tools}

The General Emotional Intelligence Scale (GEIS), developed by Albert Mehrabian, was used to measure the emotional intelligence (EI) of the high school students. The scale proposed by Mehrabian has as a theoretical model the model proposed by Mayer \&Salovey in 1997 [9]. The scale has 45 items, the first 37 items are related to emotional intelligence, and the last 8 items are related to emotional thinking. For this test, we did not take in consideration the items related to emotional thinking. The scale was designed to a ninepoint Likert scale, ranging from 1 strongly disagree to 9 strongly agree. The norms for GEIS are as follows: Mean=62; Standard Deviation=35. Alpha internal consistency for the first component is .85 and for the second component is .79 [10].

The second test used in this study is a nonverbal test developed by The University of California, Berkeley, which consists of 20 face photos with different facial expressions. The participants needed to identify the emotion expressed in each photo, choosing the right answer from four options.

\section{Results}

We conducted a one-way ANOVA to understand whether emotional intelligence in high school students differed based on the family structure where they were raised. There was not a statistically significant difference between groups, $F(2,72)=2.480$, $\mathrm{p}=.09$ (table 1).

Seeing the significant difference between the means of students with a nuclear family and students with grandparents/others family, a t-test was conducted to compare emotional intelligence in these students. There was a significant difference in the scores for students living witha nuclear family (M=60.78, $\mathrm{SD}=6.84)$ and students living with grandparents/others family $(\mathrm{M}=56.66, \quad \mathrm{SD}=6.04) \quad$ conditions; $\mathrm{t}(48)=2.26, \mathrm{p}=.03$, Cohen's $\mathrm{d}=0.64$ medium effect size. 
Table 1 ANOVA Emotional Intelligence

\begin{tabular}{|l|r|r|r|r|r|}
\hline & \multicolumn{1}{|c|}{$\begin{array}{c}\text { Sum of } \\
\text { Squares }\end{array}$} & df & $\begin{array}{c}\text { Mean } \\
\text { Square }\end{array}$ & F & Sig. \\
\hline Between & 246.993 & 2 & 123.496 & 2.480 & .091 \\
Groups & 3585.870 & 72 & 49.804 & & \\
Within Groups & 3832.863 & 74 & & & \\
Total & & & & \\
\hline
\end{tabular}

We conducted a one-way ANOVA to understand whether perceiving emotions for high school students differed based on the family structure where they were raised. There was a statistically significant difference between groups as determined by one-way ANOVA, F(2,72)=7.55, $\mathrm{p}=0.001$ (table 2). A Tukey post hoc test revealed that perceiving emotions were statistically significantly higher in students who were raised in a nuclear family $(59.76 \pm 11.20$, $\mathrm{p}=.001)$ and single-parent family (55.60 $\pm 14.16, \quad \mathrm{p}=0.024) \quad$ than grandparents/others family (45.2 \pm 15.24$)$ (table 3). However, there were no statistical differences between groups with singleparent family and nuclear family $(p=.53)$.

Table 2 ANOVA Perceiving Emotions

\begin{tabular}{|l|c|r|r|r|r|}
\hline & \multicolumn{1}{|c|}{$\begin{array}{c}\text { Sum of } \\
\text { Squares }\end{array}$} & df & $\begin{array}{c}\text { Mean } \\
\text { Square }\end{array}$ & F & Sig. \\
\hline Between & 2812.160 & 2 & 1406.080 & 7.552 & .001 \\
Groups & 13404.560 & 72 & 186.174 & & \\
Within Groups & 16216.720 & 74 & & & \\
Total & & & & \\
\hline
\end{tabular}

Table 3, Multiple Comparisons, Dependent Variable: Perceiving Emotions Tukey HSD

\begin{tabular}{|c|c|c|c|c|c|c|}
\hline \multirow[t]{2}{*}{$\begin{array}{l}\text { (I) Family } \\
\text { Structure }\end{array}$} & \multirow[t]{2}{*}{ (J) Family Structure } & \multirow{2}{*}{$\begin{array}{c}\text { Mean } \\
\text { Difference } \\
\text { (I-J) }\end{array}$} & \multirow[t]{2}{*}{$\begin{array}{l}\text { Std. } \\
\text { Error }\end{array}$} & \multirow[t]{2}{*}{ Sig. } & \multicolumn{2}{|c|}{$\begin{array}{c}\text { 95\% Confidence } \\
\text { Interval } \\
\end{array}$} \\
\hline & & & & & $\begin{array}{l}\text { Lower } \\
\text { Bound }\end{array}$ & $\begin{array}{l}\text { Upper } \\
\text { Bound }\end{array}$ \\
\hline \multirow{2}{*}{ Single-parent } & Nuclear & -4.16000 & 3.85927 & .531 & -13.3957 & 5.0757 \\
\hline & Grandparents/Others & $10.40000^{*}$ & 3.85927 & .024 & 1.1643 & 19.6357 \\
\hline \multirow{2}{*}{ Nuclear } & Single-parent & 4.16000 & 3.85927 & .531 & -5.0757 & 13.3957 \\
\hline & Grandparents/Others & $14.56000^{*}$ & 3.85927 & .001 & 5.3243 & 23.7957 \\
\hline \multirow{2}{*}{$\begin{array}{l}\text { Grandparents/ } \\
\text { Others }\end{array}$} & Single-parent & $-10.40000^{*}$ & 3.85927 & .024 & -19.6357 & -1.1643 \\
\hline & Nuclear & $-14.56000^{*}$ & 3.85927 & .001 & -23.7957 & -5.3243 \\
\hline
\end{tabular}

*. The mean difference is significant at the 0.05 level.

A paired-samples t-test was conducted to compare emotional intelligence in male and female students. There was a significant difference in the scores for female students $(\mathrm{M}=61.34, \mathrm{SD}=7.50)$ and male students $(\mathrm{M}=57.51, \quad \mathrm{SD}=6.55) \quad$ conditions; $\mathrm{t}(73)=-$ 
2.35, $\mathrm{p}=.02$, Cohen's $\mathrm{d}=0.54$ medium effect size. Our results suggested that gender influences the level of emotional intelligence, female students have a higher level of emotional intelligence than male students.

Table 4 Group Statistics

\begin{tabular}{|l|l|r|r|r|r|}
\hline & Gender & $\mathrm{N}$ & Mean & \multicolumn{1}{c|}{$\begin{array}{c}\text { Std. } \\
\text { Deviation }\end{array}$} & $\begin{array}{c}\text { Std. Error } \\
\text { Mean }\end{array}$ \\
\hline Emotional & Male & 42 & 57.5171 & 6.55410 & 1.01132 \\
Intelligence & Female & 33 & 61.3397 & 7.50339 & 1.30617 \\
\hline
\end{tabular}

Table 5 Independent Samples Test

\begin{tabular}{|c|c|c|c|c|c|c|c|c|c|c|}
\hline & \multicolumn{2}{|c|}{$\begin{array}{c}\text { Levene's } \\
\text { Test for } \\
\text { Equality of } \\
\text { Variances } \\
\end{array}$} & \multicolumn{7}{|c|}{ t-test for Equality of Means } \\
\hline & & \multirow[t]{2}{*}{$\mathrm{F}$} & \multirow[t]{2}{*}{ Sig. } & \multirow[t]{2}{*}{$\mathrm{t}$} & \multirow[t]{2}{*}{ df } & \multirow[t]{2}{*}{$\begin{array}{c}\text { Sig. } \\
(2- \\
\text { tailed })\end{array}$} & \multirow[t]{2}{*}{$\begin{array}{c}\text { Mean } \\
\text { Differen } \\
\text { ce }\end{array}$} & \multirow[t]{2}{*}{$\begin{array}{c}\text { Std. } \\
\text { Error } \\
\text { Differen } \\
\text { ce }\end{array}$} & \multicolumn{2}{|c|}{$\begin{array}{c}95 \% \\
\text { Confidence } \\
\text { Interval of the } \\
\text { Difference } \\
\end{array}$} \\
\hline & & & & & & & & & Lower & Upper \\
\hline $\begin{array}{l}\text { Emotional } \\
\text { Intelligence }\end{array}$ & $\begin{array}{l}\text { Equal } \\
\text { variances } \\
\text { assumed } \\
\text { Equal } \\
\text { variances } \\
\text { not } \\
\text { assumed }\end{array}$ & 1.21 & .27 & $\begin{array}{l}-2.35 \\
-2.31\end{array}$ & 63.93 & .021 & -3.82 & 1.62 & -7.06 & -.58 \\
\hline
\end{tabular}

A paired-samples t-test was conducted to compare perceiving emotions in male and female students. There was not a significant difference in the scores for female students $(M=54.21$, $\mathrm{SD}=17.71)$ and male students $(\mathrm{M}=52.97, \mathrm{SD}=12.25)$ conditions; $\mathrm{p}=.72$. Our results suggested that gender does notinfluence the capacity to perceive emotions.

Table 6 Group Statistics

\begin{tabular}{|ll|r|r|r|r|}
\hline & Gender & N & Mean & \multicolumn{1}{c|}{$\begin{array}{c}\text { Std. } \\
\text { Deviation }\end{array}$} & $\begin{array}{c}\text { Std. Error } \\
\text { Mean }\end{array}$ \\
\hline Recognize & Male & 42 & 52.9762 & 12.25041 & 1.89028 \\
Emotions & Female & 33 & 54.2121 & 17.70903 & 3.08275 \\
\hline
\end{tabular}


Table 7 Independent Samples Test

\begin{tabular}{|c|c|c|c|c|c|c|c|c|c|c|}
\hline & \multicolumn{2}{|c|}{$\begin{array}{c}\text { Levene's } \\
\text { Test for } \\
\text { Equality } \\
\text { of } \\
\text { Variances } \\
\end{array}$} & \multicolumn{7}{|c|}{ t-test for Equality of Means } \\
\hline & & $\mathrm{F}$ & Sig. & $\mathrm{t}$ & $\mathrm{df}$ & $\begin{array}{l}\text { Sig. } \\
\text { (2- } \\
\text { tailed) }\end{array}$ & $\begin{array}{c}\text { Mean } \\
\text { Differen } \\
\text { ce }\end{array}$ & $\begin{array}{l}\text { Std. Error } \\
\text { Difference }\end{array}$ & \begin{tabular}{|r}
95 \\
Confi \\
Interva \\
Diffe \\
\end{tabular} & $\begin{array}{l}\% \\
\text { dence } \\
l \text { of the } \\
\text { rence }\end{array}$ \\
\hline & & & & & & & & & Lower & Upper \\
\hline $\begin{array}{l}\text { Recognize } \\
\text { Emotions }\end{array}$ & $\begin{array}{l}\text { Equal } \\
\text { variances } \\
\text { assumed } \\
\text { Equal } \\
\text { variances } \\
\text { not } \\
\text { assumed }\end{array}$ & 2.37 & .13 & -.34 & 54.57 & .73 & -1.23 & 3.46 & -8.14 & 5.67 \\
\hline
\end{tabular}

In our study, there is no correlation between emotional intelligence and perceiving emotions. There is no evidence that students with a higher level of emotional intelligence can perceive emotions better than students with a lower level of emotional intelligence.

Table 8 Correlations

\begin{tabular}{|ll|r|r|}
\hline & $\begin{array}{c}\text { Emotional } \\
\text { Intelligence }\end{array}$ & $\begin{array}{c}\text { Perceiving } \\
\text { Emotions }\end{array}$ \\
\hline Emotional & Pearson & 1 & .212 \\
Intelligence & Correlation & & \\
& Sig. (2-tailed) & 75 & .068 \\
& $\mathrm{~N}$ & .212 & 75 \\
Perceiving & Pearson & & 1 \\
Emotions & Correlation & .068 & \\
& Sig. (2-tailed) & 75 & 75 \\
\hline
\end{tabular}

\section{Discussion}

Although we thought the family structure has a statistically significant influence on emotional intelligence, the current study did not validate this hypothesis. Looking at this information in a positive light we can suppose that children are receiving 
attention from caregiverswho are in charge of their education regardless of whetherit is a single-parent, a grandparent, a neighbour or both parents. Or, we could assume that because the students from this study are living in Bucharest where there are a lot of afterschool programs geared towards improving emotional intelligence, the students are benefiting by being a part of them.Or, we can look at the fact that there is no difference in the level of emotional intelligence in high school students based on family structure as a warning that perhaps none of the studentsare receiving adequateattention from their parents/caregivers. We already stated that parents are spending less time with their children. There are statisticswhich show a rise in violence at schools, so this hypothesis is worthy of being taken into consideration. The median level of emotional intelligence of the three groups is below average which makes us think that the second option may be true. A further study should be conducted to see if students who are raised in a nuclear family have sufficient attention from their parents, and I propose for the sample population to be taken from different regions in Romania. If this is the case we should be worried, and the school should intervene by introducing into the school curriculum activities which will help children develop their emotional intelligence. Additionally, involving NGOs who have emotional developmental programs would be welcomed.

When we narrow emotional intelligence to the aspect of perceiving emotions we discover that perceiving emotions is influenced by the family structure. Children who are raised in a nuclear family can perceive emotions easierthan children who are raised by grandparents or another adult. Since statistics reveal an increase in the number of children who are left at home alone by parents who go to work in a foreign country we suggest that the school definitely needs to take into consideration ways to develop this aspect in their students. We know that if you are not capable of recognizing others' emotions you are most likely struggling to recognize your own emotions. Not knowing what you feel and why you feel it can result in destructive behaviour. Gender influences the level of emotional intelligence. Females have a higher level of emotional intelligence than males. We did not find a correlation between emotional intelligence and perceiving emotion, so in our case the higher level of emotional intelligence in students raised in a nuclear or single-parent family can be due to the other aspects of emotional intelligence. It would be interesting to conduct a further study to discover if an aspect of emotional intelligence differs between students who are raised in different family structures.

\section{References}

[1] UNICEF, Alternative Sociale. (2008). Analiză la nivel naţional asupra fenomenului copiilor rămaşi acasă prin plecarea părinţilor la muncă în străinătate. Buzău: Alpha MDN, 2008.

[2] http://copiisinguriacasa.ro/pentru-specialisti/studii-si-cercetari/situatia-copiilor-ai-carorparinti-sunt-plecati-la-munca-in-strainatate/

[3] http://www.insse.ro/cms/ro/content/statistica-oficială-din-românia

[4] https://ec.europa.eu/eurostat/statisticsexplained/index.php?title=Marriages_and_births_in_Romania/ro\#Divor.C5.A3ialitatea

[5] Goleman, D., Inteligenţa Emoţională. Bucureşti: Curtea Veche, 2008.

[6] Goleman, D., Emotional Intelligence. Why it can matter more than IQ, London, Bloomsbury, 1996, p.22. 
[7] Durlak, J. A., \&Weissberg, R. P., A major meta-analysis of positive youth development programs, Invited presentation at the Annual Meeting of the American Psychological Association, Washington, DC, August, 2005.

[8] Nelson, D. B. \& Low, G.R., Emotional Intelligence: Achieving academic and career excellence in college and in life, Upper Saddle River, Pearson Higher Education, NJ, 2003.

[9] Mayer, J. D., \&Salovey, P. (1997). What is emotional intelligence? In P. Salovey\& D. J. Sluyter (Eds.), Emotional development and emotional intelligence: Educational implications, New York, Harper Collins, 1997, pp. 3-34.

[10] Mehrabian, A., Manual for the General Emotional Intelligence Scale (GEIS), Monterey, CA, 2001. 